\title{
TOWARDS AN AMS RADIOCARBON CHRONOLOGY OF PREDYNASTIC EGYPTIAN CERAMICS
}

\author{
Stephen H Savage \\ Department of Anthropology, Box 872402, Arizona State University, Tempe, Arizona 85287-2402 USA. \\ Email: shsavage@asu.edu.
}

\begin{abstract}
The wide and varied connections between Israel and Egypt during the Early Bronze Age/Predynastic are frequently calibrated through ceramics that depend to a large degree on two seriation methods developed for Predynastic Egypt. Petrie's seriation technique and Kaiser's Stufe dating method utilize whole forms from mortuary contexts. Because of the ways they were developed and deployed in Predynastic research, a logical tautology exists that makes their usage highly problematic. Radiocarbon dating of the Predynastic is vital if we are to untangle existing ceramic chronologies. But up to now, almost all ${ }^{14} \mathrm{C}$ dates have come from domestic contexts where whole vessels are not usually found and which differ significantly from cemeteries in their ceramic assemblages. A ${ }^{14} \mathrm{C}$-based chronology of whole forms in the Petrie Corpus is thus highly desirable, but has proven elusive until now. Samples of organic materials and Black-Topped Red Ware vessels from over 100 graves in the Predynastic Cemetery, N7000, at Naga-ed-Dêr have recently been submitted for dating with AMS methods, providing the first comprehensive ${ }^{14} \mathrm{C}$ chronology of a Predynastic cemetery. The results are compared to a suite of recalibrated dates from Upper Egyptian Predynastic domestic contexts, which allows the ${ }^{14} \mathrm{C}$ chronology for the region to be further refined. Absolute date ranges for a number of ceramic forms can be estimated for the first time, and results of early analysis are discussed.
\end{abstract}

\section{INTRODUCTION}

In this paper I report preliminary results from my efforts to develop a radiocarbon-based chronology of some predynastic ceramics. The study uses materials collected in 1902-1903 from the predynastic Egyptian cemetery, N7000, at Naga-ed-Dêr, Upper Egypt (Lythgoe 1905; Lythgoe and Dunham 1965). The materials were recovered as part of the Hearst Expedition to Egypt, and are curated at the Hearst Museum. Cemetery N7000 contained 635 graves and about 900 burials. NSF funding has been secured to collect, date, and evaluate 100 samples from the cemetery. The samples are currently being run at the at the NSF-Arizona AMS Facility. This paper reports results from 30 samples in the current batch and 12 samples from an earlier set of submissions. Since the analysis is just beginning, not all the dates are available yet. I am writing this paper from the field, so these results should be considered as preliminary. However, when complete, this dating program will be, by far, the largest ever conducted on Predynastic Egyptian materials. It promises to make important contributions to our understanding of this critical period in the development of the Egyptian state and its connections throughout the ancient Near East. Moreover, the results should help resolve a number of long-term problems that exist in dating the Predynastic. The dates are critical to developing a more accurate interpretation of complex spatial patterns seen in the cemetery itself, which have been interpreted as burial grounds of separate descent groups at Naga-ed-Dêr.

\section{BACKGROUND TO THE RESEARCH}

Much of the prehistory of the ancient Near East is dependent on synchronisms with the chronology of Egypt. In particular, synchronizing the Bronze Age in the Levant and Syria depends on the chronology of the Egyptian Predynastic Period, and on the critical date for the unification of Upper and Lower Egypt and accession of the 1st Dynasty. The later Predynastic, for example, is frequently dated externally by reference to ledge-handled jars imported from Canaan, but the Early Bronze I and II periods in Canaan are just as frequently dated by the appearance of pre- and protodynastic pottery (Albright 1965; Kantor 1992; Stager 1992). As a result of the critical connections between Egypt and the rest of the Middle East, and the dependence of the region as a whole on the chronol-

(C) 2001 by the Arizona Board of Regents on behalf of the University of Arizona

Near East Chronology: Archaeology and Environment. RADIOCARBON, Vol 43, Nr 3, 2001, p 1255-1277

Proceedings of the 17 th International ${ }^{14} \mathrm{C}$ Conference, edited by $\mathrm{H}$ J Bruins, I Carmi, and E Boaretto 
ogy of Egypt, considerable attention has been devoted to controlling time in predynastic and dynastic Egyptian archaeology. Methods based on ceramic or spatial seriation, textual analysis (including astronomical observations), and ${ }^{14} \mathrm{C}$ dates have been used. Petrie (1901) invented ceramic seriation to date predynastic graves he had excavated; later Kaiser (1957) developed different techniques based on grave placement in the predynastic cemetery at Armant and re-evaluated Petrie's results. Recently Kemp (1982) used multivariate statistical methods (essentially a form of correspondence analysis) to develop a ceramics-based chronology.

Textual analysis leads Egyptologists to place the founding of the 1st Dynasty between 3100 and 2900 BC (Hoffman 1982; Trigger 1983). For example, Hayes (1970) estimated the beginning of the 1st Dynasty from the Turin "Royal Canon," the document that contains Manetho's king list that established the traditional division of the historical period in Egypt into dynasties. Manetho said that the time from the founding of the 1st to the end of the 8th Dynasty was 955 years. Based on these clues, and working backward from known dates in the later periods, Hayes calculated the date for the beginning of the 1st Dynasty to be either 3119 or 3089 BC. Among other astronomical events, the helical rising of the star Sothis (Sirus), which heralded the beginning of the inundation, was carefully observed and recorded in Egypt. These records provide a date of about $2000 \mathrm{BC}$ for the beginning of the 12th Dynasty and the Middle Kingdom, and a later recorded observation places the beginning of the 18th Dynasty at about $1580 \mathrm{BC}$. However, working back from these dates presents problems because of the uncertain length of individual reigns in some cases, and of the First Intermediate Period in general (Kantor 1992). Breasted stated that working backwards from the known dates was no better than "dead reckoning" (1964:17).

\section{DATING THE PREDYNASTIC PERIOD}

Much of our understanding of the Predynastic cultural sequence is based on relative ceramic chronologies. Three different methods have been developed and will be discussed below: 1) Petrie's (1901) Sequence Dating; 2) Kaiser's (1957) Stufe dating system, and 3) Kemp's (1982) Multidimensional Scaling (MDS) method (also see Hendrickx 1993, 1996; Mortenson 1991: 11-18 for a discussion of these methods).

\section{Petrie's Sequence Dating Method}

By 1895 Petrie had excavated over 3000 Predynastic graves in the Upper Egyptian cemeteries at Nagada and Ballas. He recorded over 700 forms of pottery from these cemeteries based on a rather inconsistent typology of form, paste, and decoration (Petrie and Quibell 1896). In 1898-99 he worked through the cemeteries at Abadiyeh and Hu. By 1901 he had worked out a method of seriation or "Sequence Dating" for the graves from the various cemeteries. Petrie lumped his over 700 pottery forms into nine "ware" classes, based partly on paste, decoration, and on what he thought were chronological factors. These ware types included B-Ware, (Black-topped Red), P-Ware (Polished Red), F-Ware (Fancy forms), C-Ware (White Cross-lined), N-Ware ("Nubian" Incised Black), W-Ware (Wavy-handled), D-Ware (Decorated), R-Ware (Rough-faced), and L-Ware (Late forms) (Petrie 1901). Then, using 900 graves with five pots or more in each, Petrie made strips of paper for each grave, with the number of pots of each type in separate columns. With 900 strips of paper there would be a huge number of possible orderings, so Petrie employed two "shortcuts" to make the task easier. First, he had noted that the class of wavy-handled jars (W-Ware) proceeded from a relatively globular form with pronounced handles (based on the "Ledge-handled Jars" from Canaan) to an upright cylinder with only a wavy painted line representing the handle. He had found the later, cylindrical varieties in early Dynastic period graves, so he used this assumed development as a "key" to 
order the later part of his sequence. Second, he used his C-Ware to order the graves where no WWare was found.

Petrie's goal was to arrange the columns so that the largest frequencies of the different forms concentrated along the diagonal of his matrix of 900 graves and 9 types. Kendall (1971) called this technique "the Petrie Concentration Principle." The result was a series which progressed across the strips from earliest to latest, anchored at the late end by W-Ware. Having obtained what he felt was the best ordering of the graves based on his knowledge of C-Ware and W-Ware, Petrie divided the 900 graves into "Sequence Dates" (S.D.) each containing 18 graves. To these he assigned the numbers 30 through 80 . Wisely, Petrie left sequence dates unassigned at the beginning in case an earlier culture should be discovered, which it subsequently was at Badari by Brunton and Caton-Thompson (1928).

Later Petrie divided the whole range into three groups, which he termed Amratian, Gerzean, and Semainean-names derived from "type" sites where particular ceramic forms had first been identified. The first two terms were widely adopted by other scholars and continue in use by some (e.g. Friedman 1994; Kantor 1992), though his Semainean period was not, owing to its rather ambiguous definition at the type site of Semaineh and the inability of others to discern such a period at other places (see Kantor 1944). Some researchers (e.g. Mace 1909; Hoffman 1982) have used the term "Protodynastic" to refer to the period between the end of the Gerzean and the beginning of the Dynastic Age.

It was not long before other scholars began noticing problems with Petrie's shortcuts. For example, Scharff (1926:73) noticed that the large, globular, wavy-handled jars (Petrie's form W1) co-occurred with one of the supposedly more degenerate forms (Petrie's form 24) at Abusir El Meleq in Lower Egypt. The globular forms were found in numerous other contexts much later than those assigned to them by Petrie. As Friedman notes, though, "nevertheless, owing to the geographical distance between Abusir El Meleq in Lower Egypt and the Upper Egyptian Nagada culture, Scharff was unwilling to reject the S.D. system as a whole, but simply stated that Petrie's system did not work well in the cemeteries of the north" (Friedman 1981:2). Later Baumgartel re-examined the material that Petrie used to create his system and concluded that the wavy-handled jars were not well dated. The earliest, Petrie's W1 form, had been purchased rather than excavated. Baumgartel believed that all of the wavy-handled forms were contemporary except for the First Dynasty cylindrical shapes (1955:42; also c.f. Kantor 1947:77), and graves from Cemetery N7000 contain all the shapes except the "earliest" and "latest" (Lythgoe and Dunham 1965). Kaiser also found the chronological differences between the globular and upright forms to be extremely small, though Petrie never implied that each of his fifty sequence dates was of equal length. In fact, Friedman points out that since there are more ceramics in later Predynastic graves (see Castillos 1982, 1983), the later sequence dates probably represent shorter time spans, while the earlier Sequence Dates, dominated by B and CWares, probably represent longer periods (Friedman 1981:6-7). Essentially, then, Petrie's system works in its broad outline (Amratian, Gerzean, and Semainan or Protodynastic) but is not very reliable in its details.

\section{Kaiser's Stufe Dating Method}

As early as 1928, Guy Brunton, using Petrie's Sequence Dating, noticed that certain cemeteries in Middle Egypt exhibited temporal clustering in space. For example, Badari Cemetery 3800 has the earliest graves in the center and later graves placed to the east and west (Brunton and Caton-Thompson 1928:51). Werner Kaiser (1957) attempted to overcome some of the difficulties with Petrie's system by developing a dating method that takes advantage of the horizontal stratification observed 
by Brunton as well as typological differences in Predynastic ceramics. This was an attempt to date the contents of tombs in part by the position of the grave, rather than dating the graves according to their contents. His system divides the Predynastic into three main periods, Nagada I, II, and III, and several sub-periods (stufen). Using the map of Armant published by Mond and Meyers (1937), Kaiser divided the cemetery into three main periods based on relative percentages of B-Ware, R-Ware, and L-Ware. Eleven, and later 15 sub-periods (Kaiser 1990) were created based on ceramic type clustering within the main periods: Stufe ("Stage") Ia-Ic, Stufe IIa-IId2, Stufe IIIa1-IIIb2. These subdivisions relied heavily on the spatial distribution of ceramic types because only 115 forms occurred more than once, and many were found in only two graves (Kaiser 1957:69; also c.f. Patch 1991:157161). W-Ware, C-Ware, and D-Ware were fitted into the system rather than used to determine it because they were relatively rare forms at Armant. Kaiser's system validates Petrie's work in some respects, since his broad divisions, Nagada I through III, generally parallel Petrie's. Nagada I is roughly synonymous with Amratian, Nagada II with Gerzean, and Nagada III with Semainean or Protodynastic (Kantor 1992:7).

Many scholars have adopted Kaiser's Stufe dating system since it validates and expands on Petrie's system of three main periods in the Predynastic, while eliminating some of the problems. There are, however, several difficulties in the Stufe system. First, it appears somewhat tautological. Brunton used Petrie's Sequence Dates to infer temporal drift in Predynastic cemeteries (Brunton and CatonThompson 1928). Then Kaiser used this spatial patterning to develop his Stufe dates and assign ceramic forms to his subdivisions.

The "space-as-time" assumption that underlies Kaiser's system is based on Brunton's time-as-space observation at Badari, and reaches its greatest extreme when graves that contain no artifacts are dated, presumably on the basis of dated graves nearby (extant data files for the Naga-ed-Dêr cemetery contain such dates for empty graves). If the assigned Sequence Date of a given grave can vary by as much as twenty sequence dates on either side, as Kaiser (1957:69) noted, then the underlying spatial pattern that Brunton observed may be a result of incorrect grave dates, meaning that any subsequent dating based on the spatial pattern that he observed is also questionable. And the problem cannot be corrected by re-dating the cemeteries with the Stufe system and then checking their spatial layout, since that would create an even more vicious tautology. When Friedman applied Kaiser's system at Naga-ed-Dêr, she found that the relationship between space and grave dates were not clear-cut in Cemetery N7000 (1981:70). Rather than early graves being confined to only one area, and later graves to another, in a form of "drift," Friedman found several areas with graves from a variety of Kaiser's Stufen.

A second problem associated with the Stufe dating system is the way it has been adopted throughout the rest of Egypt. The forms that Kaiser assigned to his various stufen have been used like "index fossils" by other archaeologists to re-date graves in other cemeteries and to date the deposits on settlement sites "from Hierakonpolis in the far south (Adams 1987) to Buto in the north-western Delta (von der Way 1991)" (Wilkinson 1996:10). Application of the system in this manner assumes a uniform developmental sequence for ceramics throughout all of Egypt, but this assumption has not been tested. Indeed, it cannot be tested using the Stufe system or Petrie's sequence dates, because to do so would be to create another tautology. Only an independent dating method, external to the seriation techniques being tested, can prove or disprove the underlying assumption of ceramic uniformity. ${ }^{14} \mathrm{C}$ dating seems to be the only secure method available.

Even without ${ }^{14} \mathrm{C}$ dating, the implicit assumption of uniform ceramic development that underlies many applications of the traditional chronometrics is being replaced by an understanding of the 
regional character of Predynastic ceramic production and development. Naville stated emphatically that "for pottery, the only true classification is not chronological: it is geographical, or rather, local" (1914:xi). Scharff (1928) suggested that there were regional variations in Petrie's C-Ware class, and Finkenstaedt distinguishes three principle regions, each of which "produced a type of $\mathrm{C}$ ware peculiar to it." She infers that "in some cases, individual sites evolved a distinctive local variation on the regional style" (1981:7). Kaiser himself warned that differences between sequences at Armant and Nagada might reflect differences in development at the two sites (1957:73). More recently Patch notes that "it would be surprising if all Predynastic sites followed the same development" (1992: 192). Finally, Freidman's analysis of ceramics from the settlements at Hierakonpolis, Nagada, and Hemamiah found that "previously suspected, but poorly defined, regional differences within the Amratian settlement ceramic assemblages in each of the geographical regions were clearly apparent from an examination of the utilitarian pottery or kitchen wares at each site" (1994:865). Tempering exhibits the largest regional differences, but Friedman also notes variation in manufacturing technique, surface treatment, and shape. She also identifies "minor, but possibly regionally significant morphological differences" in the B-Wares and P-Wares (1994:871), sufficient to rule out the notion that the ceramics came from a single production center, and further expands on Finkenstaedt's (1981) observed regional differentiation in the C-Ware class. The results of Friedman's exhaustive study parallel those of Holmes' (1989), who documents differences in the lithic assemblages in the same areas. These distinct regional differences make it difficult to justify a normative, "index fossil" approach to dating Predynastic ceramics.

\section{Multivariate Analysis}

The tautological nature of the assumptions that underlie traditional approaches to Predynastic chronology, the regional nature of the ceramic assemblages, and the internal difficulties in the Stufe dating system suggest that a fresh approach is needed. Barry Kemp (1982) used a multi-dimensional scaling (MDS) program, HORSHU, to test the sequence of graves in Cemeteries A and B at el'Amrah, Armant 1400-1500, and el-Mahasna. MDS, like correspondence analysis, is a form of "dual scaling," that can arrange both cases and types in chronological order (see Nishisato 1980). HORSHU, developed by Kendall (1971) specifically to automate the process Petrie used to create his original seriation, can handle no more than one hundred graves because of the computationally intensive nature of non-metric MDS (see Shennan 1990:281-283 for a brief discussion of MDS). Kemp condensed the Petrie corpus into 43 types for his analysis, and distinguished three clusters of graves based on their ceramic types. The clusters are interpreted to confirm Petrie's basic division of the Predynastic into Amratian, Gerzean, and Semainean (and the major divisions in Kaiser's Stufe dating method), although Kemp's division between Amratian/Nagada I and Gerzean/Nagada II appears somewhat later than Petrie's.

Since Kemp's initial computer seriation others have used similar methods: 1) Seidlmayr (1990) employed seriation to identify local chronologies at individual sites, and then correlated the results. 2) Wilkinson (1996) used the Bonn Seriation Program (a form of correspondence analysis, see Scollar 1993) to develop independent chronologies at eight different Predynastic and early dynastic sites. He subsequently correlated them by connecting the various phases from the sites to the Stufe system. However, his results were hampered by lack of external dating controls, such as those provided by ${ }^{14} \mathrm{C}$ dating, and 3) Savage $(1995,1997)$ used correspondence analysis to date 143 graves from Cemetery N7000 at Naga-ed-Dêr, and concluded that they should be grouped into four use phases that span parts of the three Predynastic periods (essentially late Nagada I, all of Nagada II, and early Nagada III). Like Friedman's earlier work, it appeared that there were graves from all four use phases in most parts of the cemetery. The results suggested that spatial clusters observed in the cem- 
etery were the burial grounds of separate descent groups. Twelve ${ }^{14} \mathrm{C}$ dates from graves on Savage's seriation curve helped establish an absolute time range for the N7000 cemetery (Savage 1998; see below).

To summarize, there are clear problems with traditional chronological methods. While the three methods used in the past all agree on a tripartite division of the Predynastic, they disagree on further subdivisions, and attempts to rectify problems in any method by resorting to another and then re-dating graves in the first method only create tautological nightmares. Furthermore, the regional variation in Predynastic ceramic assemblages is generally not considered (but see Wilkinson 1996 for a notable exception), meaning that chronological schemes worked out in one place tend to be applied uncritically in other places. The whole question of "space as time" rests on an assumption that needs to be verified by an external, independent dating method. O'Shea stresses the importance of independent reference points: "precise dating, particularly dating that is independent of the material culture and behavior being examined (as in radiometric dating), provides a critical underpinning for any serious anthropological research into the past" (1996:16). The only way out of the current muddle is to develop a ${ }^{14} \mathrm{C}$ based chronology.

\section{Dating the Predynastic with Radiocarbon Methods}

${ }^{14} \mathrm{C}$ dates have been obtained from many Predynastic and dynastic sites (for some recent compilations see Close 1980, 1984, 1988; Derricourt 1971; Hassan 1984, 1985; Kantor 1992). Hassan (1988:138) tentatively suggests a Predynastic ${ }^{14} \mathrm{C}$ chronology as follows: Early Predynastic 40003900 BC, Middle Predynastic 3900-3650 BC, Late Predynastic 3650-3300 BC, Terminal Predynastic 3300-3050 BC.

Because of the history of Egyptian archaeological research, essentially, there are two parallel chronological schemes for the Predynastic period. The first, based on relative methods, is exemplified by Petrie's (1901), Kaiser's (1957), and Kemp's (1982) work with whole or reconstructed ceramics from cemetery contexts. The second is based more on sherds for its ceramic typology, and on ${ }^{14} \mathrm{C}$ dates obtained mostly from settlement sites (and tombs from the later dynastic period). However, the ceramic assemblages in settlement sites are different than those in cemeteries (e.g. decorated, marl clay pots, termed "D-Ware" by Petrie, are very rare in settlements [see Hoffman 1987] but fairly common in cemeteries; low-fired, coarse clay pans, called "Bread Molds," are hardly ever found in cemeteries but are abundant in settlements, and R-Ware sherds seem to occur much earlier in settlement sites than they do in cemeteries). The two chronological systems are not well connected. Predynastic cemetery sites remain largely undated by ${ }^{14} \mathrm{C}$ methods, and the possibility exists that cemetery chronologies may not coincide with those from settlements.

Cemetery contexts contain by far the largest body of excavated material from the Predynastic in Upper Egypt. They are virtually the only source of whole vessels and the best source of organic remains that are specifically associated with individual, dateable events (the interment). Furthermore, other Near Eastern chronological schemes tie into the Predynastic and Dynastic Egyptian dates primarily through the presence of ceramics recovered from cemeteries. Thus, an ideal solution to the chronological problems in the Predynastic and the Bronze Age would be to develop a radiocarbon chronology based on whole forms from cemeteries. Such a goal is clearly in line with Bruins and Mook's (1989:1024) assertion that, "many more samples from ancient Egypt ought to be investigated, as urged in the 1969 [Olsson 1970] Twelfth Nobel Symposium."

At present, there are very few dates from Predynastic cemeteries-fewer than $200{ }^{14} \mathrm{C}$ dates have been published from Upper Egypt; fewer than 20 are from mortuary contexts. Five of these are 
based on older methods, and they were calculated on materials gathered from a number of contexts. For example, Libby's sample C-810 consisted of about 3 ounces of human hair from four different graves at Nagada, which had different sequence dates in Petrie's scheme. In addition, Libby's dates have wide standard deviations (about 300 years), so the $95 \%$ confidence intervals extend over 1,200 years. As a result, many of the extant dates from Predynastic cemeteries are not as precise as we would like (and I think the early results soured Egyptologists on ${ }^{14} \mathrm{C}$ dating before the method was sufficiently developed to produce reliable results). Three dates from graves at Hierakonpolis have been secured. Sample BM-1127A from Tomb 100 at Hierakonpolis is clearly problematic at 12,900 \pm 120 BP. (Burleigh 1983:364). Another Tomb 100 (BM-1127B) date has a calibrated one-sigma range of 235 years at 3900-3665 BC (Burleigh 1983:364), but its wide error estimate is not useful for a more precise ${ }^{14} \mathrm{C}$ chronology or for a comparison to the tomb's ceramic inventory. At Hierakonpolis Locality 6, Tomb 1 was nearly empty when excavated-many of the sherds were recovered from an adjacent spoil pile presumed to have been left by plunderers (Hoffman 1982:41). Comparing the ${ }^{14} \mathrm{C}$ date to the original tomb contents is not possible.

Hassan and Robinson (1987) note that "the existing corpus of ${ }^{14} \mathrm{C}$ measurements for ancient Egypt is, with a few exceptions, not fully satisfactory." Since most of what we know about the Predynastic period in Upper Egypt comes from cemetery excavations, a ${ }^{14} \mathrm{C}$ based chronology of the cemeteries is needed. Such a chronology could be used to help establish a concordance between cemetery and settlement contexts. In addition, a cemetery-based ${ }^{14} \mathrm{C}$ series would allow us to test hypotheses related to ceramic chronology and cemetery use and development.

Unfortunately, most of the known Predynastic cemeteries were excavated in the late 19th or early 20 th centuries, long before ${ }^{14} \mathrm{C}$ techniques were available. Hence, it is often necessary to rely on materials collected in some cases more than a century ago. Many excavators did not collect samples of materials suitable for ${ }^{14} \mathrm{C}$ analysis, or the extant materials are not well provenienced. Some otherwise well-documented materials, which would have been suitable for dating, were treated with petrochemically based preservatives in the days before ${ }^{14} \mathrm{C}$ dating, thus ruining them for assays. As a result, there has been considerable doubt about whether a ${ }^{14} \mathrm{C}$ chronology could be recovered from Predynastic cemeteries.

What is needed is a Predynastic cemetery dug in a well-controlled manner, where there is an abundance of uncontaminated materials dateable by ${ }^{14} \mathrm{C}$ methods, and thorough documentation. Not many Predynastic cemeteries fulfill these requirements, but, happily, Cemetery N7000 at Naga-edDêr does. The excavators, Albert Lythgoe (1965) and G.E. Smith, took careful field notes, mapped the entire cemetery and drew virtually every grave; they provided provenience information on artifacts, and took over 1500 large-format photographs. In addition, they recovered many organic objects, which are now curated at the Hearst Museum of Anthropology, U.C. Berkeley.

\section{Initial Dates}

As a result of Friedman's (1981) and Savage's $(1995,1997,1998)$ efforts considerable progress has been made in establishing a firm chronological foundation in Cemetery N7000. Friedman (1981: Appendix III) estimated Sequence Date ranges and Stufe dates for graves in the cemetery with ceramics. Podzorski (1995, personal communication) estimated dates for graves that did not contain ceramics, using their proximity to those that did, (based on the questionable assumption that "space equals time"). Correspondence analysis (CA) was used to analyze 143 graves, each with a minimum of three ceramic vessels, and at least two ceramic ware "types," to establish four use phases in the cemetery (Savage 1995:98-104). CA reduces variability in the data under analysis by producing a set of scores along "Eigenvectors." A CA result captures temporal variation when a scatterplot of 
points on the first two Eigenvectors assumes a linear to horseshoe shape (Bech 1988; Bolviken et al. 1982; Hojlund 1988; Holm-Olsen 1988; Madsen 1988). The CA seriation plot from Cemetery N7000 (Figure 1) matches such a shape, capturing temporal variation well.

A number of graves on the seriation curve contained organic materials (Figure 1, numbers). In 1995 16 samples from 15 graves were submitted for ${ }^{14} \mathrm{C}$ analysis to the NSF-Arizona AMS Facility (Figure 1, underlined numbers). These materials were donated by the Hearst Museum of Anthropology to test whether the organic items from Cemetery $\mathrm{N} 7000$ were still viable for ${ }^{14} \mathrm{C}$ dating, and to help fix Savage's seriation curve in absolute time.

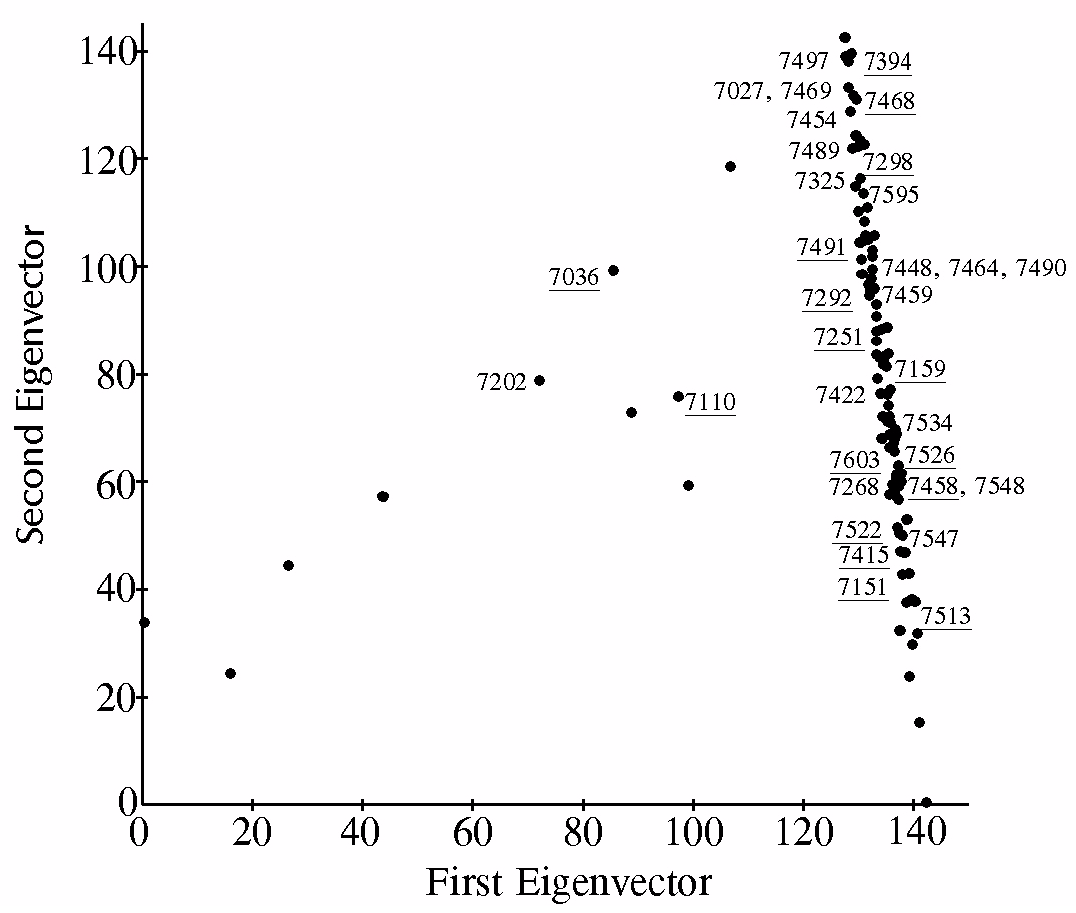

Figure 1 Results of the CA-based seriation of 143 graves from Cemetery N7000 (Savage, 1995, 1998)

Twelve ${ }^{14} \mathrm{C}$ dates were obtained (Table 1); four of the samples were not of sufficient size after cleaning to be dated, but larger samples are dateable. Using Bayesian methods to combine dates calibrated with the OxCal program (Bayes 1763; Iversen 1984; see Bronk-Ramsey 1995) Savage concluded that there were four ${ }^{14} \mathrm{C}$-based use phases in Cemetery N7000 (Table 2), indicating that the cemetery was most likely in use between about 3800 and 3090 BC (two-sigma ranges). The cemetery's phases correspond remarkably well with the four use phases developed independently through seriation (Savage 1998:242-43). Then, by recalibrating a series of 58 published dates from Upper Egypt and using the same methods to combine the results Savage (1998: Table 4, Figure 5) suggested that each of Hassan's ${ }^{14} \mathrm{C}$-based periods in the Predynastic could be divided into two smaller phases (EP I and II, MP I and II etc.). A comparison of the four use phases from Cemetery N7000 to the recalibrated phasing from Upper Egypt showed remarkable correspondence (Savage 1998: 243-47, Figure 2): Naga-ed-Dêr Phase 1 corresponds to the Middle Predynastic II, Phase 2 to the 


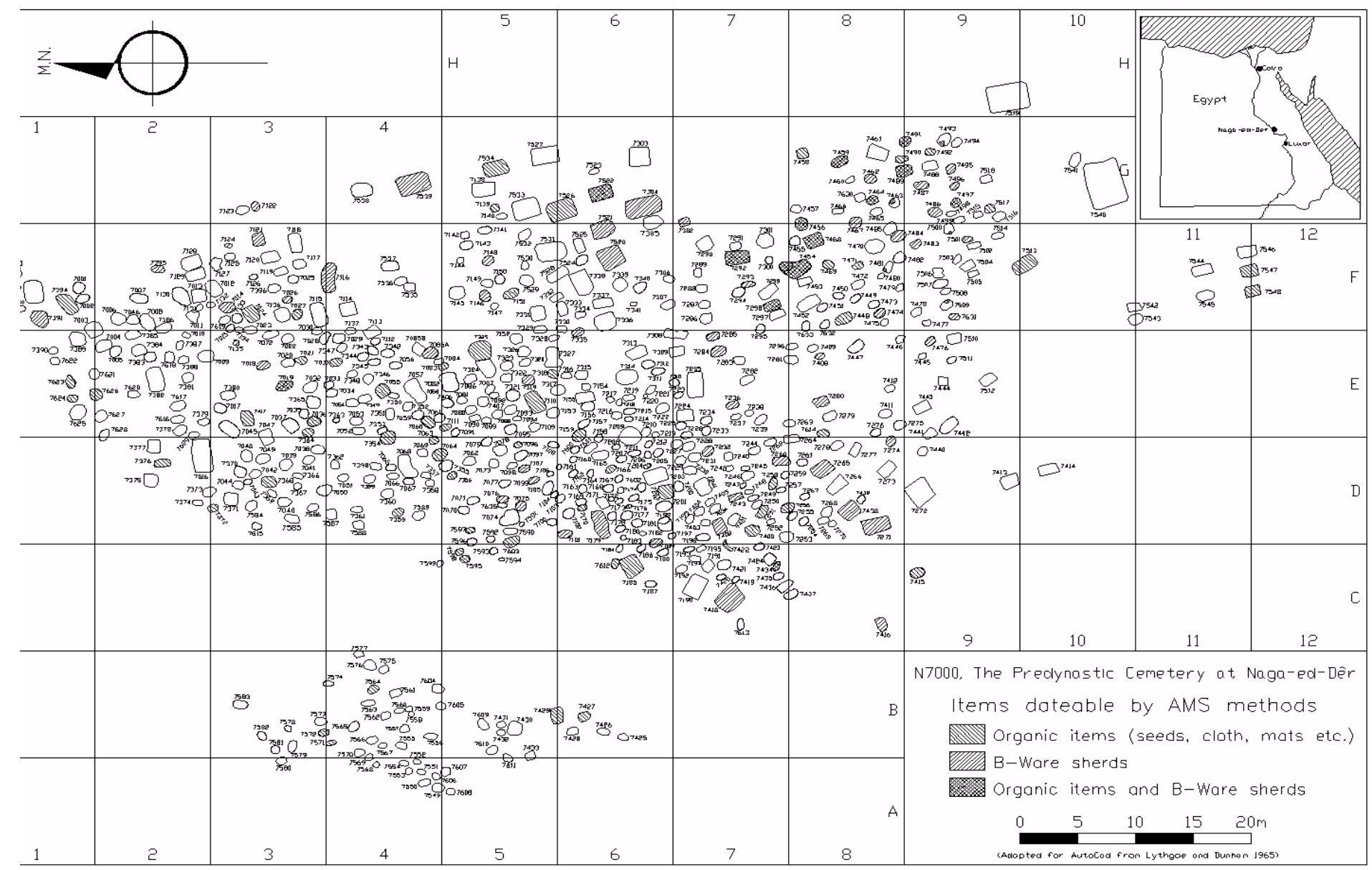

Figure 2 The predynastic cemetery N7000 at Naga-ed-Der showing grave numbers and locations of datable items. 
Late Predynastic I, Phase 3 to the Late Predynastic II, and Naga-ed-Dêr Phase 4 dated to the Terminal Predynastic 1 (thus helping fill a gap in Hassan's ${ }^{14} \mathrm{C}$ chronology from Upper Egypt).

Table 1 AMS radiocarbon dates from Cemetery N7000 at Naga-ed-Dêr (from Savage 1998)

\begin{tabular}{cllll}
\hline Grave & Sample nr & UCLMA $^{1}$ & Item & Uncalibrated \\
\hline 7036 & AA16770 & $6-12009$ & Matting from beneath burials & $4775 \pm 90$ \\
7110 & AA16771 & $6-12021$ & Leather pouch at pelvis of burial B & $4840 \pm 85$ \\
7151 & AA16772 & $6-12024$ & Seeds from pot 7151-5, (7151-5.1)3 & N.D. \\
7159 & AA16773 & $6-12025$ & Charred vegetal matter, in pot 7159-4, (7159-4.1) & $4775 \pm 75$ \\
7251 & AA16774 & $6-12033$ & Vegetal matter from pot 7251-5, (7251-5.1) & $4615 \pm 65$ \\
7292 & AA16775 & $6-12039$ & Vegetal matter from pot 7292-6, (7292-6.1) & $4505 \pm 70$ \\
7298 & AA16776 & $6-12041$ & Vegetal matter from pot 7298-3, (7298-3.1) & N.D. \\
7394 & AA16777 & $6-12058$ & Animal hair from left wrist of burial E, (7394-18) & $4950 \pm 60$ \\
7458 & AA16785 & $6-3763 . b$ & Cloth from neck of burial B, (7458-13) & N.D. \\
7468 & AA16778 & $6-12082$ & Vegetal matter from pot 7468-1, (7468-1.1) & $4560 \pm 85$ \\
7491 & AA16779 & $6-12091$ & Human hair from below pot 7491-1, (7491-10) & $4720 \pm 65$ \\
7513 & AA16780 & $6-12097$ & Vegetable matter from pot 7513-3, (7513-3.1) & $4525 \pm 70$ \\
7522 & AA16781 & $6-12103$ & Cake of vegetal matter in pot 7522-20 (7522-20.1) & $4605 \pm 65$ \\
7526 & AA16782 & $6-12105$ & Grain/seeds from pot 7526-9, (7526-9.1) & $4645 \pm 70$ \\
7603 & AA16783 & $6-12128 a^{4}$ & Cloth pouch near thigh/pelvis, 7603-5 & N.D. \\
\hline 7603 & AA16784 & $6-12128 b 4$ & Lower matting, 7603-5 & $4690 \pm 85$ \\
\hline
\end{tabular}

${ }^{1}$ UCLMA numbers refer to concession numbers at the Hearst Museum.

${ }^{2}$ Libby half life (5568 years).Radiocarbon years BP.

${ }^{3}$ Numbers such as 7151-5 refer to item numbers in Lythgoe and Dunham (1965). Numbers which extend past their sequence were added by cross-reference to UCLMA catalog cards, the Lythgoe and Dunham description and the field notes; these numbers are given in parentheses (see Savage 1995:Volume 2). Designations such as 7151-5.1 are used for vessel contents.

${ }^{4}$ These two samples were taken from the same UCLMA object, which preserves part of the cloth pouch adhering to the matting.

This initial test of the viability of organic materials from the Predynastic cemetery at Naga-ed-Dêr showed that the objects curated at the Hearst Museum are capable of producing reliable, and vital AMS dates. Preservatives and contamination do not appear to be a significant problem; initial pretreatment is able to remove spurious wood wool or cotton fibers from the original packing materials used in 1904, thus allowing the samples to be dated. These results contribute to a badly needed, calibrated ${ }^{14} \mathrm{C}$ chronology for Predynastic cemetery remains from Upper Egypt. They constitute one of 
the first series of AMS dates to be run on Predynastic cemetery remains, and the results fit well with the recalibrated chronology of the Upper Egyptian sequence derived mostly from settlements.

Table 2 Cemetery N7000 use phases based on combined dates (from Savage 1998)

\begin{tabular}{cccccc}
\hline Phase & Graves & 1 sigma range1 & 1 sigma p2 & 2 sigma range3 & 2 sigma p \\
\hline 1 & 7110,7394 & $3760-3740$ & 0.19 & $3800-3630$ & 1.00 \\
$(\mathrm{MP} \mathrm{I})^{4}$ & & $3720-3640$ & 0.81 & & \\
2 & 7036,7159, & $3630-3500$ & 0.82 & $3640-3500$ & 0.73 \\
$(\mathrm{LP} \mathrm{I})$ & 7491 & $3410-3380$ & 0.18 & $3460-3370$ & 0.27 \\
3 & 7251,7522, & $3500-3450$ & 0.62 & $3510-3340$ & 1.00 \\
$($ LP II $)$ & 7526,7603 & $3380-3350$ & 0.38 & & \\
4 & 7292,7468, & $3340-3290$ & 0.26 & $3360-3090$ & 1.00 \\
$($ TP I $)$ & 7513 & $3240-3100$ & 0.74 & & \\
\hline
\end{tabular}

${ }^{1} 68.2$ percent confidence overall. Calendar years BC.

2 Probability of date falling into alternative date ranges.

395.4 percent confidence overall. Calendar years BC.

${ }^{4}$ MP I, LP I, LP II, TP I correspond to sub-phases based on recalibrated dates from Upper Egypt (see Savage 1998).

\section{METHODS AND PROCEDURES}

\section{Selection of Samples}

Much of the material available for dating consists of vegetable matter contained in pots that were included as grave offerings. The vegetable matter comprised mainly seeds or chaff, sometimes charred. Grain or seed offerings included in graves are thought to have originated as either the remains of a funeral meal consumed at the grave site, or as food offerings intended to accompany the deceased on their journey to the afterlife (see Adams 1988). It is likely that the age of the materials themselves corresponds very closely to that of the interment event (probably within one harvest cycle).

Other objects available for dating include human hair, matting, and leather or cloth from articles of clothing. Of these, the human hair is perhaps most problematic in terms of its connection to the burial event. The excavators observed numerous burials which included balls of human hair as grave offerings, such as graves 7055, 7130, 7491, and 7596 (samples of these are present in the Hearst Museum collections). Grave 7491, for example, included about 50 small coils and balls of fine brown hair, along with straight hair, mostly corn-yellow but with traces of the same brown in it. The straight hair corresponded to that of the hair found on the cranium. Lythgoe remarked that this provided "the solution of the balls and coils of hair found occasionally in other graves of this cemetery. It was the hair of the individual at an earlier age which had been preserved and was finally buried with the individual" (Lythgoe and Dunham 1965:310). Thus, the samples of human hair do not necessarily correspond to the burial episode itself, but to an earlier event. ${ }^{14} \mathrm{C}$ age determinations based on these hair balls would be expected to read somewhat earlier than the interment. One standard deviation of the ${ }^{14} \mathrm{C}$ date likely encompasses any discrepancy in age between the hair and the interment, but I will not use hair for dating unless it is absolutely necessary. 
Matting and clothing from the graves also are likely to correspond closely enough to the date of the interment; they are clearly somewhat earlier than the burial event itself, but probably not so much as to overly bias the ${ }^{14} \mathrm{C}$ results.

Thus, I adopted an "order of preferability" in sample selection. The items most directly related to the funeral event are seeds or grain stored in pots deposited in the grave, or stomach contents of the bodies; I selected these items first, obtaining as wide a distribution in the cemetery as possible. Matting that wrapped the bodies is also closely related to the interment, and graves with matting samples was chosen as second priority. Clothing probably dates closely to the time of interment, and ceramics may have been manufactured specifically for the mortuary ritual (see Hoffman 1989). Ceramics were sampled specifically to judge whether they date closely to the time of other dated items in specific graves. Finally, all items were located in the Museum by Ms. Leslie Freund, and the samples were collected by Ms. Margaret Fang, both of the Hearst the Museum staff. Every effort was made to sample items whose specific location in the grave was shown by field drawings (see Savage 1998: Figures 2 and 3; Figure 4).

Care was taken to select samples whose dating will accomplish as many goals as possible. One goal is to test the dates of graves in close proximity so some samples were collected from adjacent, or nearly adjacent graves. However, another goal of the research is to date graves in every part of the cemetery, so samples were collected from widely dispersed graves as well (see Figure 3). Finally, since I wanted to test some notions about graves without ceramics, and develop an absolute chronology for some ceramic forms, I chose samples from graves with large numbers of pots, and from graves with no pots. The final determinations were made based on the condition and quantity of dateable items. All samples were taken in accordance with standard archaeological practices (e.g. Bowman 1990; Dancey 1981:163-64), wrapped in aluminum foil, and delivered to the NSF-Arizona AMS Facility. Only items with secure proveniences were sampled-that is, only items described in Lythgoe's field notes, and which have an existing catalog card at the Museum. Sample sizes were in accordance with requirements published by the NSF-Arizona AMS Facility (NSF-UA, 1994).

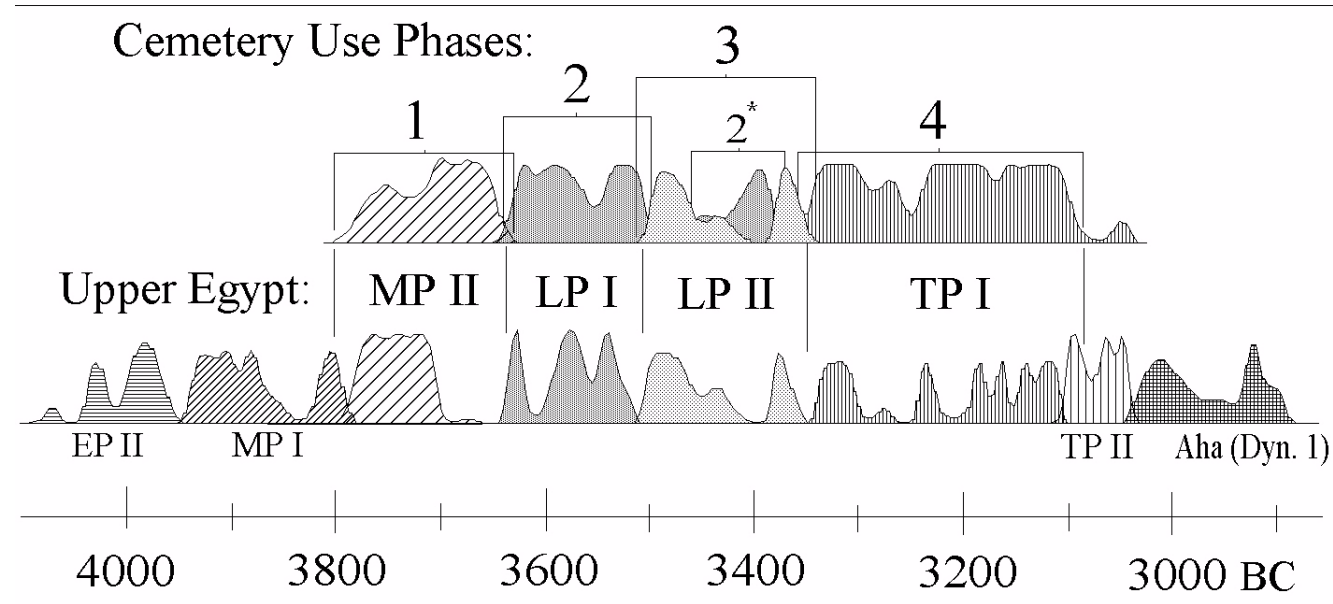

Figure 3 Cemetery N7000 use phases compared to recalibrated dates and phases from Upper Egypt. 


\section{Animal hair (probable bracelet) from left wrist of Burial $\mathrm{E}$.}

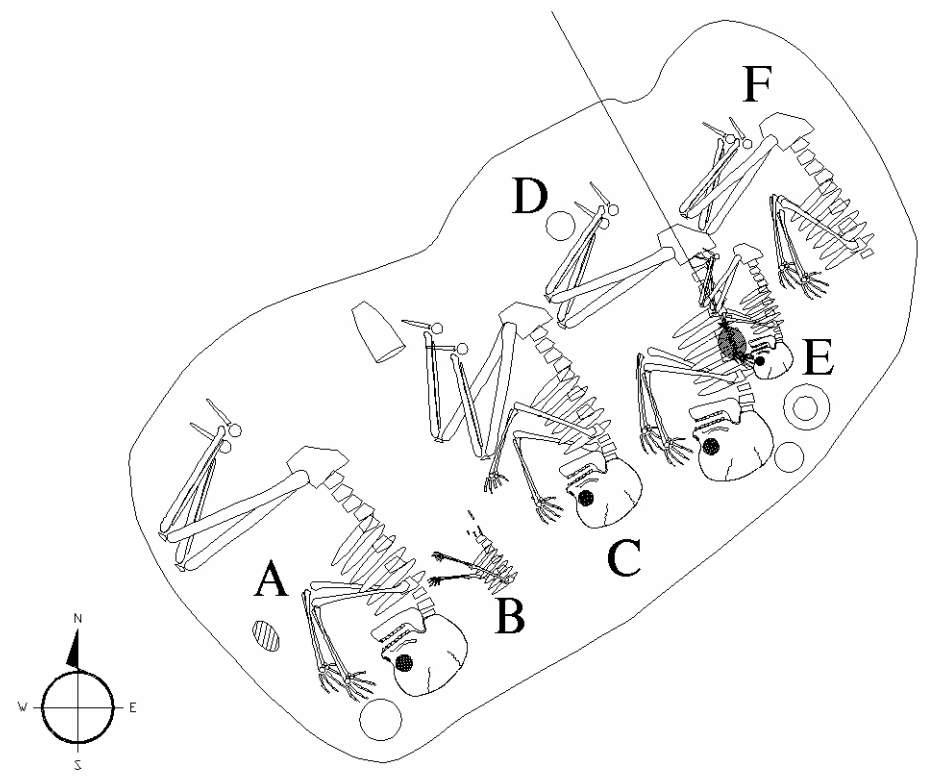

Figure 4 Grave N7394, showing location of dateable item

\section{Sample Treatment}

Since several different kinds of organic materials were submitted for dating, a variety of different pretreatment methods were required. Table 3 lists the pretreatment method used for each sample. These methods are summarized by Tim Jull (personal communication):

Samples were ${ }^{14} \mathrm{C}$-dated using accelerator mass spectrometer at the University of Arizona. Samples for ${ }^{14} \mathrm{C}$ dating were pretreated using 4 different protocols, depending on the type of material. These were as follows:

1. Due to the degradation of some of the textile materials, these samples had to be treated very carefully, some samples were only given a wash in $1 \mathrm{~N} \mathrm{HCl}$.

2. More robust samples of textile, basketry and other plant-fibre material were given the standard acid-base-acid pretreatment using $1 \mathrm{~N} \mathrm{HCl}$ and $\sim 0.1 \% \mathrm{NaOH}$.

3. Leather samples were given the acid-base-acid treatment and then further cleaned using soxhlet extractions in hexane, ethanol and methanol, followed by a distilled water washing. Samples from pretreatments 1 to 3 were then combusted with $\mathrm{CuO}$ using standard procedures at the Arizona laboratory.

4. Pottery samples were given the standard acid-base-acid pretreatment. These samples were then combusted in oxygen at $400{ }^{\circ} \mathrm{C}$ using the procedure of O'Malley et al (1998). As noted by Delque-Kolic (1995), this will allow organic material in the pottery to be oxidized to $\mathrm{CO}_{2}$, but potentially "older" carbon trapped in clay minerals will not be oxidized.

The pretreatment and combustion procedure adopted for each sample is noted in Table 3. After combustion, the $\delta^{13} \mathrm{C}$ of the gas, or a split of the gas if larger than $\sim 1 \mathrm{~cm}^{3} \mathrm{STP} \mathrm{CO} \mathrm{CO}_{2}$, was determined by 
Table 3 Raw and calibrated dates from 30 graves.

\begin{tabular}{|c|c|c|c|c|c|c|}
\hline Grave & Item & Uncalibrated & $\begin{array}{l}\text { Calibrated } \\
(1 \text { sigma })^{1}\end{array}$ & $\begin{array}{l}\text { Calibrated } \\
(2 \text {-sigma })^{2}\end{array}$ & $\begin{array}{l}\text { Sample \#, } \\
\text { Treatment }^{3}\end{array}$ & Comment \\
\hline 7454 & $\begin{array}{l}\text { Vegetal matter } \\
\text { from pot }\end{array}$ & $5530 \pm 140$ & $\begin{array}{l}4540(66.9 \%) 4220 \\
4180(1.3 \%) 4170\end{array}$ & $4700(95.4 \%) 4000$ & $\begin{array}{l}\text { AA35997 85\% g } \\
\text { aba }\end{array}$ & $\begin{array}{l}\text { Wide standard deviation renders date of } \\
\text { little value. }\end{array}$ \\
\hline 7107 & B-War jar & $5513 \pm 51$ & $\begin{array}{l}4450(18.0 \%) 4420 \\
4400(43.4 \%) 4320 \\
4280(6.9 \%) 4250\end{array}$ & $4460(95.4 \%) 4240$ & $\begin{array}{l}\text { AA36043 } \\
400 \mathrm{EC}\end{array}$ & $\begin{array}{l}\text { Very early result will require cross- } \\
\text { checking. }\end{array}$ \\
\hline 7122 & $\begin{array}{l}\text { B-Ware jar; Pot } \\
7122-2 \text {. }\end{array}$ & $5501 \pm 52$ & $\begin{array}{l}4450(12.7 \%) 4420 \\
4400(5.5 \%) 4380 \\
4370(33.3 \%) 4320\end{array}$ & $4460(95.4 \%) 4240$ & $\begin{array}{l}\text { AA36045 } \\
400 \mathrm{EC}\end{array}$ & $\begin{array}{l}\text { Possibly earlier than expected, due to } \\
\text { associated R and P -Ware forms. }\end{array}$ \\
\hline 7547 & $\begin{array}{l}\text { Vegetal matter } \\
\text { from pot }\end{array}$ & $5440 \pm 50$ & $4345(68.2 \%) 4245$ & $\begin{array}{l}4370(84.5 \%) 4210 \\
4200(7.2 \%) 4160 \\
4130(3.8 \%) 4050\end{array}$ & $\begin{array}{l}\text { AA35980 } \\
\text { aba }\end{array}$ & $\begin{array}{l}\text { Another seemingly early result. Contains } \\
\text { P- and R-Ware. }\end{array}$ \\
\hline 7354 & Charcoal & $5383 \pm 38$ & $\begin{array}{l}4330(27.4 \%) 4270 \\
4260(23.3 \%) 4220 \\
4200(15.0 \%) 4160 \\
4120(2.4 \%) 4110\end{array}$ & $\begin{array}{l}4340(58.5 \%) 4210 \\
4200(20.0 \%) 4140 \\
4130(16.9 \%) 4040\end{array}$ & $\begin{array}{l}\text { AA35979 } \\
\text { aba }\end{array}$ & $\begin{array}{l}\text { Probably an early result; grave contains two } \\
\text { D-Ware forms. }\end{array}$ \\
\hline 7492 & Vegetal matter & $5310 \pm 690$ & $5000(68.2 \%) 3300$ & $5700(95.4 \%) 2400$ & $\begin{array}{l}\text { AA36013 28\% g } \\
\text { aba }\end{array}$ & $\begin{array}{l}\text { Wide standard deviation renders date of no } \\
\text { value. }\end{array}$ \\
\hline 7274 & $\begin{array}{l}\text { B-Ware jar; } \\
\text { Pot 7274-1 }\end{array}$ & $5310 \pm 49$ & $\begin{array}{l}4230(11.7 \%) 4180 \\
4170(56.5 \%) 4040\end{array}$ & $\begin{array}{l}4320(2.9 \%) 4290 \\
4260(92.5 \%) 3980\end{array}$ & $\begin{array}{l}\text { AA } 36047 \\
400 \mathrm{EC}\end{array}$ & B $25 \mathrm{H}$ corpus form. \\
\hline $7085 \mathrm{~A}$ & $\begin{array}{l}\text { B-Ware pot; } \\
7085 \mathrm{~A}-5\end{array}$ & $5258 \pm 59$ & $\begin{array}{l}4220(10.8 \%) 4190 \\
4170(15.8 \%) 4120 \\
4110(5.2 \%) 4090\end{array}$ & $4250(95.4 \%) 3960$ & $\begin{array}{l}\text { AA36044 } \\
400 \mathrm{EC}\end{array}$ & $\begin{array}{l}\text { B } 29 \text { E3 form seems early, as there are } \\
\text { R-Ware forms in the grave. }\end{array}$ \\
\hline 7571 & $\begin{array}{l}\text { Leather pouch, at } \\
\text { legs }\end{array}$ & $5217 \pm 50$ & $\begin{array}{l}4220(0.11) 4200 \\
4140(0.01) 4130 \\
4050(0.88) 3960\end{array}$ & $\begin{array}{l}4230(0.11) 4190 \\
4170(0.89) 3940\end{array}$ & $\begin{array}{l}\text { AA36040 } \\
\text { aba }\end{array}$ & B-Ware beaker and jar. \\
\hline
\end{tabular}


Table 3 Raw and calibrated dates from 30 graves.

\begin{tabular}{|c|c|c|c|c|c|c|}
\hline 7517 & $\begin{array}{l}\text { Cakes of vegetal } \\
\text { matter from Pot } \\
7517-1 .\end{array}$ & $5119 \pm 48$ & $\begin{array}{l}3980(0.38) 3930 \\
3880(0.62) 3800\end{array}$ & $\begin{array}{l}4040(0.02) 4020 \\
3990(0.98) 3790\end{array}$ & $\begin{array}{l}\text { AA36039 } \\
\text { soxhlet }\end{array}$ & Grave contains B 58 A corpus form. \\
\hline 7416 & B-Ware jar & $5113 \pm 86$ & $3990(68.2 \%) 3790$ & $\begin{array}{l}4250(3.3 \%) 4100 \\
4050(92.1 \%) 3700\end{array}$ & $\begin{array}{l}\text { AA36042 } \\
400 \mathrm{EC}\end{array}$ & $\begin{array}{l}\text { Date on a B } 53 \text { b form. Also has a P2 } 24 \mathrm{~K} \\
\text { bowl and } 3 \text { R-Ware forms }\end{array}$ \\
\hline 7271 & B-Ware jar & $5056 \pm 50$ & $3950(68.2 \%) 3790$ & $3970(95.4 \%) 3710$ & $\begin{array}{l}\text { AA36046 } \\
400 \mathrm{EC}\end{array}$ & $\begin{array}{l}\text { Seems to be early!grave includes B, P, R, and } \\
\text { W-Ware forms. }\end{array}$ \\
\hline 7111 & $\begin{array}{l}\text { Folded leather and } \\
\text { rolled cloth at right } \\
\text { leg. }\end{array}$ & $4955 \pm 52$ & $3780(1.00) 3660$ & $\begin{array}{l}3940(0.10) 3870 \\
3810(0.90) 3640\end{array}$ & $\begin{array}{l}\text { AA36015 } \\
\text { soxhlet }\end{array}$ & $\begin{array}{l}\text { Leather sampled. Grave contains } \\
\text { P2 } 22 \text { A bowl. }\end{array}$ \\
\hline 7497 & B-Ware jar & $4810 \pm 130$ & $\begin{array}{l}371 \\
0(52.6 \%) 3490 \\
3460(15.6 \%) 3370\end{array}$ & $3950(95.4 \%) 3300$ & $\begin{array}{l}\text { AA36011 } \\
400 \mathrm{EC}\end{array}$ & $\begin{array}{l}\text { Wide standard deviation covers full range of } \\
\text { Predynastic period at } 2 \text {-sigma. }\end{array}$ \\
\hline 7458 & $\begin{array}{l}\text { Cloth fragments at } \\
\text { neck. }\end{array}$ & $4800 \pm 50$ & $\begin{array}{l}3650(0.23) 3620 \\
3600(0.77) 3520\end{array}$ & $\begin{array}{l}3700(0.92) 3500 \\
3430(0.08) 3380\end{array}$ & $\begin{array}{l}\text { AA35999 } \\
\text { aba }\end{array}$ & Contains B, P, and R-Ware forms. \\
\hline 7491 & Matting over knees & $4794 \pm 51$ & $\begin{array}{l}3650(0.21) 3620 \\
3600(0.79) 3520\end{array}$ & $\begin{array}{l}3690(0.90) 3500 \\
3440(0.10) 3370\end{array}$ & $\begin{array}{l}\text { AA36036 } \\
400 \mathrm{EC}\end{array}$ & $\begin{array}{l}\text { B } 72 \text { A, P2 } 22 \text { A, P2 } 14 \text { G, P 11D, R 22b } \\
\text { corpus forms. }\end{array}$ \\
\hline 7055 & $\begin{array}{l}\text { Cloth; probably a } \\
\text { head cloth. }\end{array}$ & $4791 \pm 48$ & $\begin{array}{l}3650(13.6 \%) 3620 \\
3600(54.6 \%) 3520\end{array}$ & $\begin{array}{l}3660(86.3 \%) 3500 \\
3430(9.1 \%) 3370\end{array}$ & $\begin{array}{l}\text { AA36004 } \\
\text { aba }\end{array}$ & No pottery from this grave. \\
\hline 7027 & $\begin{array}{l}\text { Cloth garments, } \\
\text { covered body head to } \\
\text { feet. }\end{array}$ & $4776 \pm 52$ & $3640(68.2 \%) 3510$ & $\begin{array}{l}3660(79.6 \%) 3490 \\
3460(15.8 \%) 3370\end{array}$ & $\begin{array}{l}\text { AA36000 } \\
\text { aba }\end{array}$ & $\begin{array}{l}\text { B } 11 \text { E, P2 } 14 \text { g; unsp. small B-Ware jar \& R- } \\
\text { Ware bowl fragment. }\end{array}$ \\
\hline 7204 & $\begin{array}{l}\text { Cloth, from feet, } \\
\text { pelvis \& vertebral } \\
\text { column. }\end{array}$ & $4770 \pm 190$ & $\begin{array}{l}3800(66.6 \%) 3300 \\
3250(1.6 \%) 3100\end{array}$ & $4000(95.4 \%) 3000$ & $\begin{array}{l}\text { AA35998 } \\
\text { aba }\end{array}$ & $\begin{array}{l}\text { Wide standard deviation covers entire } \\
\text { Predynastic period; no pottery. }\end{array}$ \\
\hline 7019 & $\begin{array}{l}\text { Cloth, from between } \\
\text { legs }\end{array}$ & $4716 \pm 49$ & $\begin{array}{l}3630(21.7 \%) 3580 \\
3540(16.4 \%) 3490 \\
3460(30.1 \%) 3370\end{array}$ & $3640(95.4 \%) 3370$ & $\begin{array}{l}\text { AA36010 } \\
\text { aba }\end{array}$ & B 57 B/A form (see Armant Cemetery) \\
\hline
\end{tabular}




\begin{tabular}{|c|c|c|c|c|c|c|}
\hline 7623 & Seeds near left hand. & $4690 \pm 55$ & $\begin{array}{l}3630(8.0 \%) 3600 \\
3530(14.0 \%) 3490 \\
3470(46.2 \%) 3370\end{array}$ & $\begin{array}{l}3640(21.2 \%) 3550 \\
3540(74.2 \%) 3360\end{array}$ & $\begin{array}{l}\text { AA35978 } \\
\text { aba }\end{array}$ & No pottery from this grave. \\
\hline 7612 & $\begin{array}{l}\text { Cloth, in front of } \\
\text { face. }\end{array}$ & $4655 \pm 73$ & $\begin{array}{l}3630(4.2 \%) 3600 \\
3530(64.0 \%) 3350\end{array}$ & $\begin{array}{l}3650(87.7 \%) 3300 \\
3250(7.7 \%) 3100\end{array}$ & $\begin{array}{l}\text { AA36009 } \\
\text { aba }\end{array}$ & P2 $22 \mathrm{~A}, \mathrm{R} 74 \mathrm{C}$ corpus forms \\
\hline 7448 & $\begin{array}{l}\text { Braided cord from } \\
\text { leg area. }\end{array}$ & $4654 \pm 49$ & $\begin{array}{l}3520(58.6 \%) 3410 \\
3390(9.6 \%) 3360\end{array}$ & $\begin{array}{l}3630(7.7 \%) 3580 \\
3540(87.7 \%) 3340\end{array}$ & $\begin{array}{l}\text { AA36022 } \\
\text { aba }\end{array}$ & 7 corpus forms, including $\mathrm{B}, \mathrm{P}, \& \mathrm{R}$-Ware \\
\hline 7166 & $\begin{array}{l}\text { Cording from leg } \\
\text { area. }\end{array}$ & $4650 \pm 70$ & $\begin{array}{l}3620(1.9 \%) 3600 \\
3520(66.3 \%) 3350\end{array}$ & $\begin{array}{l}3650(87.1 \%) 3300 \\
3250(8.3 \%) 3100\end{array}$ & $\begin{array}{l}\text { AA36007 } \\
\text { aba }\end{array}$ & No pottery from this grave. \\
\hline 7469 & $\begin{array}{l}\text { Basket, on } 15 \mathrm{~cm} \text { fill } \\
\text { behind body }\end{array}$ & $4636 \pm 52$ & $\begin{array}{l}3520(0.78) 3410 \\
3390(0.22) 3350\end{array}$ & $3650(1.00) 3100$ & $\begin{array}{l}\text { AA36025 } \\
\text { aba }\end{array}$ & B 19 T, B 62 B, P2 22 A2 corpus forms \\
\hline 7456 & Cloth pouch at waist. & $4635 \pm 41$ & $\begin{array}{l}3510(54.4 \%) 3430 \\
3380(13.8 \%) 3360\end{array}$ & $\begin{array}{l}3630(1.5 \%) 3600 \\
3530(93.9 \%) 3340\end{array}$ & $\begin{array}{l}\text { AA36005 } \\
\text { aba }\end{array}$ & $\begin{array}{l}\text { B } 25 \mathrm{M}, \mathrm{B} 74 \mathrm{~K}, \mathrm{~B} 25 \mathrm{e}, \mathrm{P} 76 \mathrm{~g} \text { corpus } \\
\text { forms. Date is weighted average from } 3 \\
\text { runs. }\end{array}$ \\
\hline 7021 & Cloth at knees. & $4629 \pm 46$ & $\begin{array}{l}3510(50.9 \%) 3420 \\
3380(17.3 \%) 3350\end{array}$ & $\begin{array}{l}3630(2.2 \%) 3590 \\
3530(88.7 \%) 3330 \\
3220(1.9 \%) 3180 \\
3160(2.5 \%) 3120\end{array}$ & $\begin{array}{l}\text { AA36012 } \\
\text { acid }\end{array}$ & B 21 Q corpus form (see Badari Cemetery). \\
\hline 7415 & $\begin{array}{l}\text { Sediment. from Pot } \\
7415-6 .\end{array}$ & $4605 \pm 48$ & $\begin{array}{l}3510(37.5 \%) 3430 \\
3380(24.4 \%) 3330 \\
3210(3.1 \%) 3190\end{array}$ & $\begin{array}{l}3520(74.8 \%) 3300 \\
3240(20.6 \%) 3100\end{array}$ & $\begin{array}{l}\text { AA36008 } \\
\text { aba }\end{array}$ & $\begin{array}{l}\text { P2 } 11 \text { G, P2 } 14 \text { G, R } 66 \text { A, D } 67 \text { D21 (see } \\
\text { Badari Cemetery), P2b2 corpus forms }\end{array}$ \\
\hline 7548 & $\begin{array}{l}\text { Seeds from pot } \\
7548-1 \text {. }\end{array}$ & $4550 \pm 80$ & $\begin{array}{l}3490(0.8 \%) 3470 \\
3370(28.2 \%) 3260 \\
3250(39.3 \%) 3090\end{array}$ & $3550(95.4 \%) 2900$ & $\begin{array}{l}\text { AA35976 } \\
74 \% \mathrm{~g}, \text { aba }\end{array}$ & $\begin{array}{l}\text { P2, R 94, R } 69 \text { R corpus forms; also } \\
\text { Mostagedda Pl. } 36 .\end{array}$ \\
\hline 7614 & Cloth from head. & $4300 \pm 200$ & $3350(68.2 \%) 2600$ & $3600(95.4 \%) 2300$ & $\begin{array}{l}\text { AA36002 } \\
\text { aba }\end{array}$ & $\begin{array}{l}\text { Wide standard deviation. B } 63 \text { A form } \\
\text { (Mahasna). }\end{array}$ \\
\hline
\end{tabular}


stable-isotope mass spectrometry. The gas was then reduced to graphite over an Fe catalyst at about $625{ }^{\circ} \mathrm{C}$ and the graphite powder was pressed into an accelerator target holder. The targets were mounted in a 32-position target wheel containing a total of 24 samples and 8 standards (4 Oxalic-I and 4 Oxalic-II). The samples were measured by AMS using the Tandetron run at $2 \mathrm{MV}$ at the University of Arizona and the results of the samples was calculated as described by Donahue et al (1990).

\section{Analysis Procedures}

After raw dates were obtained from the University of Arizona AMS facility, they were calibrated with the OxCal program, using the 1998 calibration curve (Stuiver et al. 1998). Once all the dates are in, they will be grouped with the OxCal program as well. In recent years it has been recognized that Bayesian methods of ${ }^{14} \mathrm{C}$ calibration are preferable to earlier methods (Bowman 1994:841; also see Bowman and Leese 1995). Earlier calibration routines (e.g. Stuiver and Reimer 1986) used an intercept method, but more recent programs (Bronk Ramsey 1995; Niklaus et al. 1992; Stuiver and Reimer 1993; van der Plicht 1993) have adopted a Bayesian routine which uses "the eminently reasonable a priori assumption that, in the absence of any other information to the contrary, all calendar ages for the event being dated are equally likely" (Bowman 1994:840). Furthermore, because Bayesian date combination techniques narrow the probable range of a group of dates rather than expanding the range as the Long and Rippeteau (1974) date averaging method did, it is possible to provide two-sigma date ranges that are frequently shorter than the one-sigma ranges calculated with earlier methods. The specific techniques used for grouping the dates will follow those reported in Savage (1998).

\section{Preliminary Results from the Current Study}

The Hearst Museum preserves some 210 dateable samples from 135 different graves, not counting human bone (Savage 1995:Tables A6 and A12, Figure 3). One hundred samples were submitted to the NSF-Arizona AMS Facility. Available materials include seeds from grain offerings, charcoal, stomach or intestinal contents, human bone, human and animal hair, basketry, matting, cloth, rope and cordage, and B-Ware sherds. Since Predynastic B-Ware contains a high concentration of atmospheric carbon (because the black top is produced by inverting the vessel in organic material during firing) these sherds are directly datable. One hundred ${ }^{14} \mathrm{C}$ dates will allow us to establish manufacturing date ranges for many different types of Predynastic pottery by combining ${ }^{14} \mathrm{C}$ dates from a series of graves with the same ceramic types. This should provide significant information for crossdating graves that do not contain enough ceramics for seriation or organic materials for ${ }^{14} \mathrm{C}$ dating, and will provide a series of temporal markers for comparison with other Predynastic cemeteries and settlements.

\section{New Dates}

Table 3 lists the new dates for which results have been received (30 of 100 samples). Several graves $(7454,7492,7497,7204$, and 7614) returned dates whose standard deviations that are so wide that the dates are not useful; some cover virtually the entire Predynastic period. Grave 7354 has produced a surprising result, which should be viewed with some skepticism at this juncture. It contains DWare pots, which are generally associated with the latter half of the Predynastic period, yet even its latest, calibrated, two-sigma range falls in the early part of the Predynastic (Table 3). If this result is corroborated by other early dates for Predynastic D-Ware, our current understanding of when DWare appears in the ceramic repitoire might require modification. Such a determination must await the final results, however. The remaining dates are in general accord with the earlier group of twelve 
I submitted in 1995. With these dates, I can begin to suggest some date ranges for the ceramic forms the graves contained.

Some Tentative Dates for Various Ceramic Forms. I use the ceramic type designations from the Petrie Corpus (Petrie 1928) and other sources [e.g. Armant (Mond and Meyers 1937), Badari (Brunton and Caton-Thompson 1928), Harageh (Engelbach and Gunn 1923), Mahasna (Ayrton and Loat 1911), Matmar (Brunton 1948), Mostagedda (Brunton 1937), Petrie's corpus of Protohistoric pottery (Petrie 1953), and The Archaeological Survey of Nubia (Reisner 1910)]. When the results from all 100 samples are in, they will be grouped, along with the original 12 dates, so that they can be compared with the ${ }^{14} \mathrm{C}$ phases from Upper Egypt. For the present, this paper reports some initial dates from pottery types from the original group of 12 dated graves. Later, when the rest of the results are in, more definitive date estimates will be possible for a variety of forms, because there will be many instances where specific forms are found in more than one dated grave.

Since the analysis has barely begun, the date ranges are preliminary estimates only. Figures 5, 6, and 7 illustrate some of the whole B, P, and R-Ware forms by phase. Most of the forms listed or illustrated are currently dated by only one grave, and may therefore extend past the estimated date ranges reported here. However, some forms, which occur more frequently in Predynastic graves, are better represented in the initial 12 dates as well. It is therefore possible to tentatively assign larger date ranges to them. For example, the B 74 series of Black-topped Red Ware jars extends from the LP I to the TP I (Figure 5). B 74a is currently represented in two graves, one from the LP I (number 7459), and the other from the LP II (number 7251), while the B 74c type is found in one dated grave from the TP I (number 7468). The closely related B 72a jar form is currently dated by one grave (number 7491) to the LP I, as is the more squat B 76b jar, which was first identified at Badari (Brunton and Caton-Thompson 1928), and is found in Grave 7036 at Naga-ed-Dêr. Earlier forms, such as the B 18, B 21, and B 29 beaker series, are currently represented only by graves that date to the MP II, or late Amratian (Nagada I) period. Two dated graves, numbers 7394 and 7110, contain these forms. Since there are, as of this writing, no dated graves later than MP II that contain these types, an "evolution" of B-Ware shapes from relatively straight-sided, open beaker forms to more curvilinear, and/or closed forms appears indicated, confirming earlier results from ceramic seriations, but assigning absolute time ranges for the various shapes.

\section{Black-topped red (B-Ware)}

AMS radiocarbon dates for some Predynastic Corpus forms:
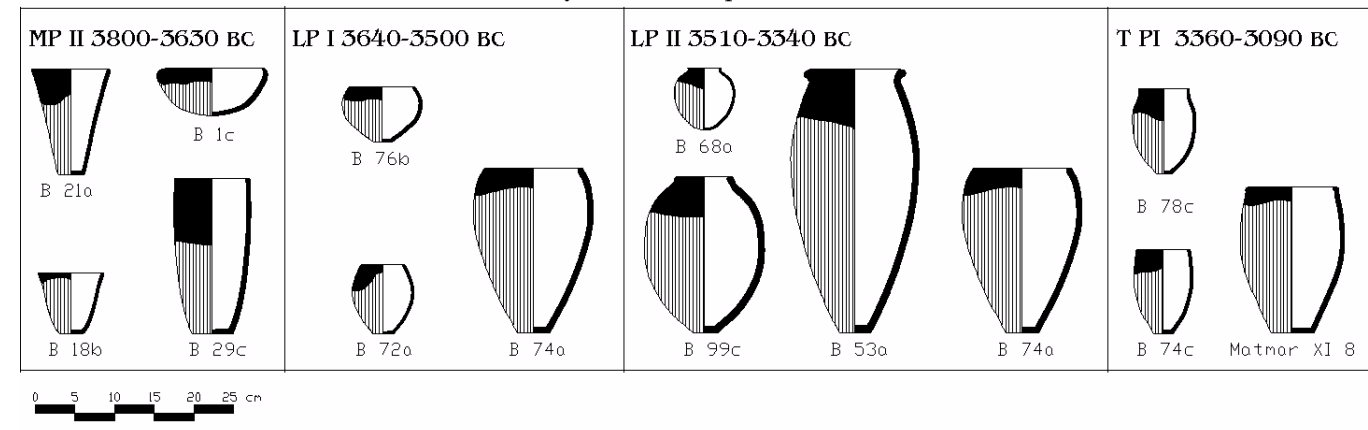

Figure 5 AMS radiocarbon dates for some B-Ware forms. 
The P 2, Polished Red Ware bowl series (Figure 6), extends across the entire use life of the cemetery, from Grave 7110 (a fragment of a P 216 form, which is not illustrated) in the MP II to a P $223 \mathrm{c}$ form in Grave 7292, dating to TP I. These results simply confirm what scholars of the Predynastic have stressed for some time- that the $\mathrm{P} 2$ bowl series has such great time depth that it is of little use in chronometric analysis.

One of the important markers that has been used to signal the transition from Nagada I to Nagada II is the appearance of Rough-faced ceramics in Predynastic Cemeteries (the transition is now thought to occur somewhat later, between Nagada II a/b and Nagada II c/d, see Friedman 1994 and Wilkinson 1996). Though R-Wares are abundant in settlement sites (Ginter and Kozlowski 1994) during the earlier part of the Predynastic, the current study suggests that their initial appearance in Cemetery N7000 at Naga-ed-Dêr may be as early as 3640 BC in the LP I, based on dates from graves 7159 and 7491. If additional dates confirm these findings, then it might be necessary to push the Nagada II a/b to Nagada II c/d transition back by approximately a century, and a corresponding shift in the Early Bronze I might be supported as well. LP I forms include the R 94 bottle series (extending into

\section{Polished red (P-Ware)}

AMS radiocarbon dates for some Predynastic Corpus forms:

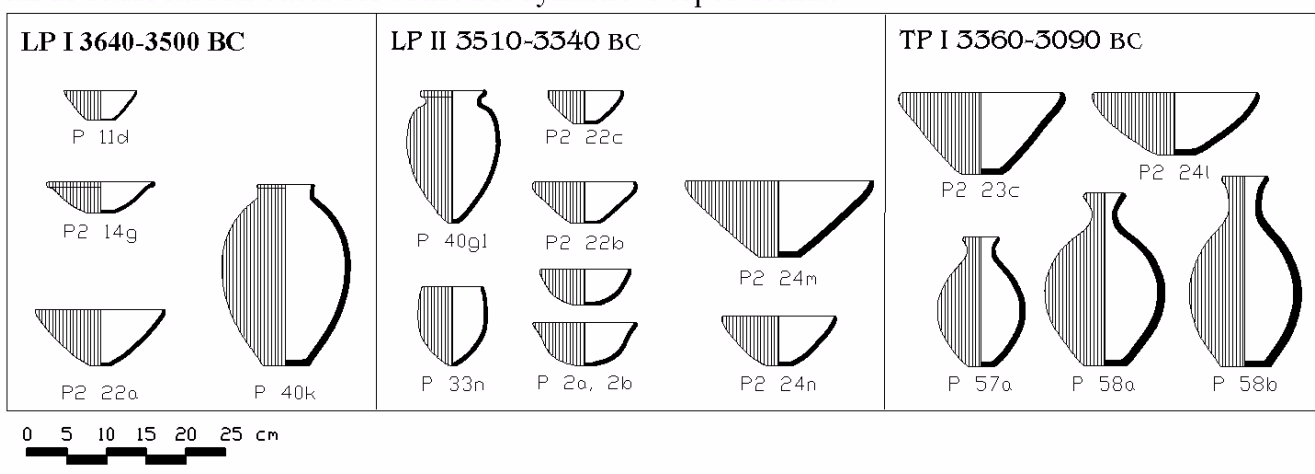

Figure 6 AMS radiocarbon dates for some P-Ware forms

LP II), the R 22 bowl types, and the initial appearance of the R 81 "Ash Jar" form, which is found throughout the rest of the Predynastic period (Figure 7).

\section{SUMMARY}

Since its development ${ }^{14} \mathrm{C}$ dating methods have been applied to ancient Egyptian materials, with varying degrees of success. Initial dates run by Libby on combined samples from several tombs in the Nagada cemeteries produced dates that had such wide standard deviations that they were of no value to Egyptologists. Perhaps those early efforts dissuaded many from attempting to use the method, in spite of the more recent refinements that allow much more precise dates to be obtained. A significant number of dates from Predynastic settlement sites have been run, and Hassan has grouped them into his Early, Middle, Late, and Terminal Predynastic phases. More recently, Savage's recalibration of some Upper Egyptian dates with the OxCal program suggests that each of Hassan's phases has an early and a late component, with two sigma confidence rather than one. In spite of these developments, though, there has been a significant gap in our ability to develop a ${ }^{14} \mathrm{C}$ 


\section{Rough faced (R-Ware)}

AMS radiocarbon dates for some Predynastic Corpus forms:

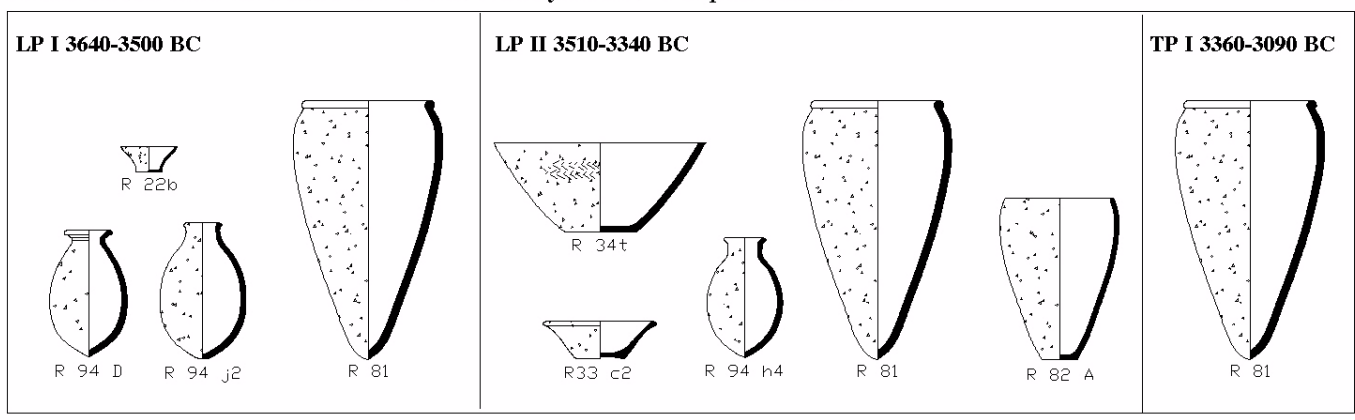

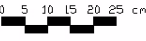

Figure 7 AMS radiocarbon dates for some R-Ware forms

chronology for the Predynastic. Earlier dating methods relied on various seriation techniques based on whole forms from cemeteries, while the more recent ${ }^{14} \mathrm{C}$ dates have been obtained almost exclusively from settlement sites. This has resulted in two parallel dating systems in the Predynastic; its critical relationship to the Early Bronze Age in the Southern Levant has been based almost exclusively on the earlier seriations. The circular reasoning that occurs in seriation studies of Predynastic ceramics renders the method suspect at best.

It would seem that the only way out of the current dilemma is to develop a ${ }^{14} \mathrm{C}$-based chronology of whole ceramic forms from cemetery contexts. The current study, while in its early stages, illustrates the value of such an approach, in that individual corpus forms can, for the first time, be assigned absolute date ranges based on solid ${ }^{14} \mathrm{C}$ evidence rather than estimates derived from the use of "index fossils" and convoluted reasoning. The initial results are encouraging: about 65 ceramic types now have date ranges assigned to them, and the whole suite of dates will allow nearly 500 types to be dated. Already the early returns suggest that the Nagada II a/b to Nagada II b/c transition may occur earlier than previously estimated, which impacts the dating of the Early Bronze Age in the Southern Levant. While I anticipate that a number of dates may have to be discarded due to insufficient carbon in the samples, I look forward to being able to publish around 80 graves with reasonable dates. Their associated pottery types, some of which will be dated directly, will provide an essential first step toward developing a ${ }^{14} \mathrm{C}$-based chronology of Predynastic ceramics.

\section{ACKNOWLEDGEMENTS}

This research has been made possible by a National Science Foundation grant \# BCS 9973067, the NSF Arizona AMS Facility in Tucson, the kind cooperation of the staff at the Phoebe Hearst Museum of Anthropology, University of California at Berkeley. The Arizona State University Graduate Student's Association provided initial travel funds in 1995.

\section{REFERENCES}

Adams B. 1987. The Fort Cemetery at Hierakonpolis. London: Kegan Paul.

Adams B. 1988. Predynastic Egypt. Shire Egyptology Series. Aylesbury: Shire Publications.

Albright WF. 1965. Some remarks on the archaeological chronology of Palestine before about 1500 B.C. In: Erich RW, editor. Chronologies in Old World Archaeology. Chicago: University of Chicago Press. p 47-60. Ayrton ER, Loat WLS. 1911. The Predynastic Cemetery at El Mahasna. Memoir 31. Egypt Exploration Fund. 
Baumgartel EJ. 1955. The Cultures of Prehistoric Egypt, Volume I. Revised edition. Oxford: Oxford University Press.

Bayes TR. 1763. An essay towards solving a problem in the Doctrine of Chances. Philosophical Transactions of the Royal Society 53:370-418.

Bech JH. 1988. Correspondence analysis and pottery chronology. A case from the Late Roman Iron Age cemetery Slusegard, Bornholm. In: Multivariate archaeology: numerical approaches in Scandinavian archaeology. Madsen T, editor. Jutland Archaeological Society Publications XXI, Aarhus University Press. p 29-36.

Bolviken E, Ericka H, Knut H, Holms-Olsen IM, Solheim L, Bertelsen R. 1982. Correspondence analysis: an alternative to principle components. World Archaeology 14(1):41-60.

Bowman SGE. 1990. Interpreting the past: radiocarbon dating. London: British Museum Publications.

Bowman SGE. 1994. Using radiocarbon: an update. $A n-$ tiquity 68:838-43.

Bowman SGE, Leese MN. 1995. Radiocarbon calibration: current issues. American Journal of Archaeology 99(1):102-5.

Breasted JH. 1964. A history of Egypt from the earliest times to the Persian conquest. New York: Bantam [originally published in 1905].

Bronk Ramsey C. 1995. OxCal program v 2.18. Oxford: Oxford Radiocarbon Accelerator Unit.

Bruins HH, Mook WG. 1989. The need for a calibrated radiocarbon chronology of near eastern archaeology. Radiocarbon 31(3):1019-29.

Brunton G. 1948. Matmar. London. Egyptian Research Account.

Brunton G, Caton-Thompson G. 1928. The Badarian civilization and predynastic remains near Badari. London: Egyptian Research Account.

Burleigh R. 1983. Two radiocarbon dates from freshwater shell from Hierakonpolis: archaeological and geological interpretations. Journal of Archaeological Science 10:361-7.

Castillos J. 1982. Analyses of Egyptian predynastic and early dynastic cemeteries: final conclusions. JSSEA XII(1):29-53.

Castillos J. 1983. A study of the spatial distribution of large and richly endowed tombs in Egyptian predynastic and early dynastic cemeteries. Toronto: Benben Publications.

Close A. 1980. Current research and recent radiocarbon dates from northern Africa. Journal of African History 21:145-67.

Close A. 1984. Current research and recent radiocarbon dates from northern Africa II. Journal of African History 25:1-24.

Close A. 1988. Current research and recent radiocarbon dates from northern Africa III. Journal of African History 29:145-76.
Dancey WS. 1981. Archaeological field methods: an introduction. Edina, Minnesota: Alpha Editions.

Derricourt RM. 1971. Radiocarbon chronology for Egypt and north Africa. Journal of Near Eastern Studies 30: 271-92.

Donahue D J, Linick TW, Jull AJT. 1990. Isotope-ratio and background corrections for accelerator mass spectrometry radiocarbon measurements. Radiocarbon 32(2):135-42.

Delque-Kolic E. 1995. Direct radiocarbon dating of pottery: selective heat treatment to retrieve smoke-derived carbon. Radiocarbon 37(2):275-84.

Engelbach R, Gunn B. 1923. Harageh. London: Egyptian Research Account.

Finkenstaedt E. 1981. The location of styles in painting: white cross-lined ware at Naqada. Journal of the American Research Center in Egypt 18:7-10.

Friedman R. 1981. Spatial distribution in a predynastic cemetery: Naga-ed-Dêr 7000 [M.A. thesis]. University of California, Berkeley.

Friedman R. 1994. Predynastic settlement ceramics of upper Egypt: a comparative study of the ceramics of Hemamieh, Nagada, and Hierakonpolis [unpublished $\mathrm{Ph}$.D. dissertation]. University of California, Berkeley. University Microfilms, Ann Arbor, Michigan.

Ginter B, Kozlowski J. 1994. Predynastic settlement near Armant, Cairo: Deutsches Archäolisches Institut.

Hassan FA.. 1980. Radiocarbon chronology of archaic Egypt. Journal of Near Eastern Studies 39:203-7.

Hassan FA. 1984. Radiocarbon chronology of predynastic Naqada settlements, upper Egypt. Current Anthropology 25(5):681-3.

Hassan FA. 1985. Radiocarbon chronology of Neolithic and Predynastic Sites in Upper Egypt and the Delta. The African Archaeological Review 3:95-116.

Hassan FA. 1988. The Predynastic of Egypt. Journal of World Prehistory 2(2):135-85.

Hassan FA, Robinson S. 1987. High-precision radiocarbon chronometry of ancient Egypt, and comparisons with Nubia, Palestine, and Mesopotamia. Antiquity 61:119-35

Hayes WC. 1970. Chronology: Egypt-to the end of the twentieth dynasty. In: Edwards IES, editor. Cambridge Ancient History. Volume 1, third edition. Cambridge. p 173-93.

Hendrickx S. 1993. Relative chronology of the Naqada culture. Paper delivered at the British Museum colloquium on early Egypt. London, 22 July 1993.

Hendrickx S. 1996. The relative chronology of the Naqada culture: problems and possibilities. In: Spencer J, editor. Aspects of Early Egypt. London: British Museum. p 36-69.

Hoffman MA. 1989. Packaged funerals and the rise of Egypt. Archaeology 42:48-51.

Hoffman MA. 1987. A final report to the national endowment for the humanities on predynastic research at $\mathrm{Hi}$ erakonpolis 1985-86 (N.E.H. Grant No. RO-20805- 
85). Earth Sciences and Resources Institute, University of South Carolina, Columbia.

Hoffman MA. 1982. The predynastic of Hierakonpolis. Egyptian Studies Association Publication No. 1. Cairo University Herbarium, Cairo.

Hojlund F. 1988. Chronological and functional differences in Arabian Bronze Age pottery. A case study in correspondence analysis. In: Madsen T, editor. Multivariate archaeology: numerical approaches in Scandinavian archaeology. Jutland Archaeological Society Publications XXI, Aarhus University Press.p.55-60.

Holmes D. 1989. The predynastic lithic industries of upper Egypt: a comparative study of the lithic traditions of Badari, Nagada, and Hierakonpolis. Cambridge Monographs in African Archaeology 33, BAR International Series 469(i).

Holm-Olsen IM. 1988. The archaeological survey of north Norway. An evaluation using correspondence analysis. In: Madsen T, editor. Multivariate archaeology: numerical approaches in scandinavian archaeology. Jutland Archaeological Society Publications XXI, Aarhus University Press.p.61-70.

Iversen GR. 1984. Bayesian statistical inference. Newbury Park: Sage Publications.

Kaiser W. 1957. Zur inneren chronologie der Nagadakultur. Archaeologia Geographica 6:69-77.

Kaiser W. 1990. Zur entstehung des gesamtägyptischen staates. MDAIK 46:115-19.

Kantor HJ. 1944. The final phase of predynastic culture, Gerzean or Semainean? Journal of Near Eastern Studies 3:110-36.

Kantor HJ. 1947. Review of "The Cultures of Prehistoric Egypt" by Elise Baumgartel. American Journal of Archaeology 53:76-9.

Kantor HJ. 1992. The relative chronology of Egypt and its foreign correlations before the first intermediate period. In: Ehrich RW, editor.Chronologies in Old World Archaeology. Third edition. Chicago: University of Chicago Press. p 3-21.

Kemp BJ. 1982. Automatic analysis of predynastic cemeteries:a new method for an old problem. Journal of Egyptian Archaeology 68:5-15.

Kendall DG. 1971. Seriation from abundance matrices. In: Hodson FR, Kendall DG, Tautu P, editors.Mathematics in the archaeological and historical sciences. Edinburgh: Edinburgh University Press. p 215-53.

Libby W. 1955. Radiocarbon dating. Second edition. Chicago: University of Chicago Press.

Long A, Rippeteau RB. 1974. Testing contemporaneity and averaging radiocarbon dates. American Antiquity 39(2):205-15.

Lythgoe AM. 1905. The Egyptian expedition of the University of California; an early predynastic cemetery at Naga-ed-Dêr. American Journal of Archaeology 9:79.

Lythgoe AM, Dows D, editors 1965. The predynastic cemetery, N7000, Naga-ed-Dêr, Part IV. Berkeley: University of California Press.
Mace AC. 1909. The early dynastic cemeteries of Nagaed-Dêr, Part II. University of California Publications, Egyptian Archaeology, Volume III. Leipzig: J. C. Hinrihs.

Madsen T, editor. 1988. Multivariate statistics and archaeology. In: Multivariate archaeology: numerical approaches in Scandinavian archaeology. Jutland Archaeological Society Publications XXI, Aarhus University Press. p 7-28.

Mond Sir Oliver, Meyers RH. 1937. Cemeteries of Armant I. London: Egyptian Exploration Society.

Mortenson B. 1991. Change in the settlement pattern and population in the beginning of the historical period. Ägypten und Levante 2:11-37.

Naville E. 1914. The cemeteries of Abydos, Part I. London: Egyptian Exploration Fund 33.

NSF-UA. 1994. NSF-University of Arizona AMS Facility. Guidelines for submitting samples for ${ }^{14} \mathrm{C}$ measurements. Tucson: University of Arizona.

Niklaus TR, Bonani G, Simonius M, Suter M, Wölfli W. 1992. CaliBETH: an interactive computer program for the calibration of radiocarbon dates. Radiocarbon 34(3):483-92.

Nishisato S. 1980. Analysis of categorical data: dual scaling and its applications. Toronto: University of Toronto Press.

Olsson IU, editor.1970. Radiocarbon variations and absolute chronology. 12th Nobel Symposium, Stockholm.

O’Malley J, Kuzmin YV, Burr GS, Donahue DJ, Jull AJT. 1998. Direct radiocarbon accelerator mass spectrometric dating of the earliest pottery from the Russian Far East and Transbaikal. Proceedings of the $3^{\text {rd }}$ International Conference " ${ }^{14} \mathrm{C}$ and Archaeology," Lyon. $\mathrm{p}$ $19-24$.

O'Shea JM. 1996. Villagers of the Maros: a portrait of an early Bronze Age society. New York: Plenum Press.

Patch DC. 1991. The origin and early development of urbanism in ancient Egypt: a regional study. Ph.D. Dissertation, University of Pennsylvania. University Microfilms, Ann Arbor, Michigan.

Petrie, Flinders WM. 1901. Diospolis Parva. Egyptian Research Account, London.

Petrie, Flinders WM. 1928. Corpus of predynastic pottery and palettes. Egyptian Exploration Society, London.

Petrie, Flinders WM. 1953. Ceremonial slate palettes and corpus of protodynastic pottery, London.

Petrie, Flinders WM, Quibell JE. 1896. Naqada and Ballas. London: Egyptian Research Account.

Podzorski P. 1995. Stufe dates for graves in cemetery N7000. Unpublished data table shared by the author.

Reisner GA. 1910. The archaeological survey of Nubia. 1907-1908 Report, Volume I, Cairo.

Savage SH. 1995. Descent, power, and competition in predynastic Egypt: mortuary evidence from cemetery N7000 at Naga-ed-Dêr. Ph.D. dissertation, Arizona 
State University. University Microfilms, Ann Arbor, Michigan.

Savage SH. 1997. Descent group competition and economic strategies in predynastic Egypt. Journal of Anthropological Archaeology 16(4):226-68.

Savage SH. 1998. AMS ${ }^{14} \mathrm{C}$ dates from the predynastic Egyptian cemetery, N7000, at Naga-ed-Dêr. Journal of Archaeological Science 25(3):235-49.

Scharff A. 1926. Die archaeologischen ergebnisse des vorgeschictlichen graberfeldes von Abusir el Meleq. Leipzig: Deutschen Orient Gesellschaft Berlin Wissenchaftliche Veroffentlichungen 49.

Scollar I. 1993. The Bonn seriation and archaeological statistics package, version 4. The Unkelbach Valley Software Works. Bonn, Germany.

Seidlmayr S J. 1990. Gräberfelder aus dem Übergang vom alten zum mittleren Reich: Studien zur archäoloue der ersten Zwischenzeit. Studien zur Archäologie und Geschechte Altägyptens 1. Heidelberg: Heidelberg Orientverlag.

Shaw IME. 1985. Egyptian chronology and the Irish oak calibration. Journal of Near Eastern Studies 44(4): 295-317.

Shennan S. 1990. Quantifying archaeology. New York: Academic Press.

Stager L. 1992. Periodization of Palestine from Neolithic through early Bronze times. In: Ehrich RW, editor. Chronologies in Old World archaeology. 3rd edition. Chicago: University of Chicago Press. p 22-41.
Stuiver M, Kra RS, editors. 1986. Calibration issue, Proceedings of the 12 th International ${ }^{14} \mathrm{C}$ Conference. $R a$ diocarbon 28(2B):805-1030.

Stuiver MA, Long A, Kra RS, editors. 1993. Calibration issue. Radiocarbon 35(1).

Stuiver M, Reimer PJ, Bard E, Beck JW, Burr GS, Hughen KA, Kromer B, McCormac G, van der Plicht J, Spurk M. 1998. INTCAL98 radiocarbon age calibration, 24,000-0 cal BP. Radiocarbon 40(3):104183.

Stuiver M, Reimer PJ. 1993. Extended ${ }^{14} \mathrm{C}$ data base and revised CALIB $3.0{ }^{14} \mathrm{C}$ age calibration program. $\mathrm{Ra}$ diocarbon 35(1):215-30.

Stuiver M, Reimer PJ. 1986. A computer program for radiocarbon age calculation. Radiocarbon 28(2B): 1022-30.

Trigger BG. 1983. The rise of Egyptian civilization. In: Ancient Egypt: a social history. Contributions by Trigger BG, Kemp BJ, O'Connor D, Lloyd AB. Cambridge: Cambridge University Press. p1-70.

van der Plicht J. 1993. The Groningen radiocarbon calibration program. Radiocarbon 35(1):231-7.

von der Way T. 1991. Die grabungen in Buto und die reichseinigung. MDAIK 47:419-24.

Wilkinson TAH. 1996. State formation in Egypt: chronology and society. In: Alexander J, editor. Cambridge Monographs in African Archaeology 40. BAR International Series 651. Oxford: Tempus Reparatum. 